\title{
Heavy Metal Contamination of Soil and Surface Water in the Arufu Lead-Zinc Mining District, Middle Benue Trough, Nigeria*
}

\author{
C. I. Adamu and T. N. Nganje
}

Adamu, C. I. and Nganje, T. N. (2010), "Heavy Metal Contamination of Soil and Surface Water in the Arufu Lead-Zinc Mining District, Middle Benue trough, Nigeria”, Ghana Mining Journal, Vol. 12, pp. 17 - 23.

\begin{abstract}
This paper is aimed at investigating the nature of heavy metals dispersion in soil and surface water around the Arufu leadzinc mine, Middle Benue Trough, Nigeria. Rock samples from mine pits and adjoining outcrops as well as water samples from mine pits and adjacent streams were collected and analyzed. Also analysed were soil samples collected from mine waste and adjoining areas as well as from a forest to serve as control. All samples were analysed for $\mathrm{Fe}, \mathrm{Zn}, \mathrm{Mn}, \mathrm{Cu}, \mathrm{Pb}$, $\mathrm{Cr}$, As, Cd and Ag, using atomic absorption spectrophotometer (AAS). Organic Matter (OM) content of the soil samples, and the $\mathrm{pH}$ of both soil and water samples were also determined. The results show that the OM content of soil was generally low $(4 \pm 1.1 \%)$ and both soil and water samples were characterized by moderate $\mathrm{pH}$ values of 6.30 to 8.00 and 5.60 to 7.80 respectively. Furthermore, soils developed over bedrock show normal (background) levels of heavy metals, while soils developed over mine waste are enriched in $\mathrm{Zn}(181 \pm 83 \mathrm{mg} / \mathrm{kg}) ; \mathrm{Pb}(40 \pm 28 \mathrm{mg} / \mathrm{kg})$ and $\mathrm{Cd}(3 \pm 2 \mathrm{mg} / \mathrm{kg})$. Also, water samples from mine ponds are enriched in $\mathrm{Pb}(0.02-0.10 \mathrm{mg} / 1)$ and $\mathrm{Cd}(0.02-0.04 \mathrm{mg} / 1)$. The sources of these heavy metals are most probably sulphides in the mine waste. Tailing and mine pits may therefore represent point sources of heavy metal contaminants and should therefore be reclaimed to prevent further contamination.
\end{abstract}

\section{Introduction}

For more than a century, the Benue Trough of Nigeria has been an area of considerable economic interest, primarily because of its $\mathrm{Pb}-\mathrm{Zn}$ mineralization. More than twenty mineralized occurrences are localized in the $600 \mathrm{~km}$ long northeastsouthwest trending belt of slightly deformed Cretaceous sediments. Arufu is one of the districts with the localized occurrences of the $\mathrm{Pb}-\mathrm{Zn}$ mineralization and as far back as 1910; the inhabitants mined the ore for cosmetic purposes. Modern small-scale mining by various foreign and indigenous mining companies has been intermittent since 1921 (Pargater,1959). At present, the mines are abandoned due to the exhaustion of ore reserves without any proper management of the mines and tailings.

According to Jung (2001), this mine waste could generate point source of heavy metal pollution in the local environment as elements are released to the biosphere at a higher rate than would occur by the natural weathering of underlying parent materials (Kelepertsis and Bibou, (1991); Pouyat, et al. (1995); Chen, et al. (1997); Wong, (1996). At Arufu, water from mine ponds are used for domestic and agricultural purposes. Besides, the mine waste together with adjoining land is being cultivated for food crop such as tubers, cereals, vegeta- bles, legumes, etc. It is, therefore, most probable that the people may be accumulating some of these heavy metals through contaminated food and water to levels that could lead to phototoxic effects (Mills, 1995).

This study therefore, attempts to investigate the degree of heavy metal contamination of soil and water in Arufu $\mathrm{Pb}-\mathrm{Zn}$ mining district, Middle Benue Trough, Nigeria. Results from this research will serve as possible guide for better understanding of the quality of food and water as well as the health status of the inhabitants.

\section{Study Area Description}

Arufu mining district of Middle Trough, Nigeria is located between longitudes $9^{\circ} 10$ and $9^{\circ} 20 \mathrm{E}$ and latitudes $7^{\circ} 40$ and $7^{\circ} 45 \mathrm{~N}$ (Fig. 1). The area which is undulating lies roughly $200-300 \mathrm{~m}$ above sea level. Laterite scarps which have resulted from prolonged dissection of former laterite sheets are dominant features in the area. Many small seasonal streams including Rivers Pii, Kutaji, Kiri and Ubaver, that are all tributaries of River Benue control the drainage in the area. The streams are structurally controlled and generally join to form a dendritic drainage pattern.

The area is characterized by the tropical wet-dry climate and the rainfall is generally moderate,

* Manuscript received June 23, 2009

Revised version accepted March 12, 2010 


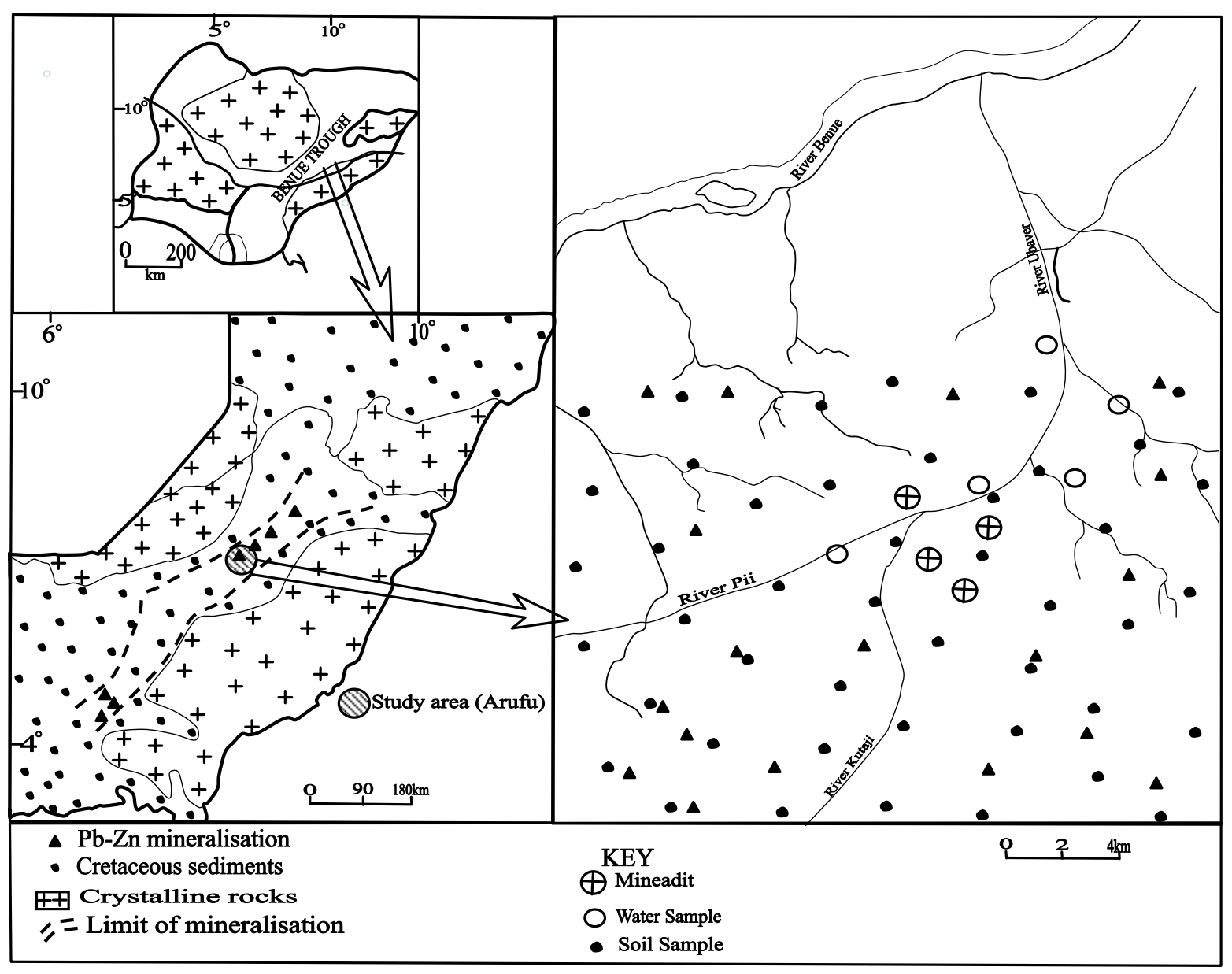

Fig. 1 Simplified Geological Map of Benue Trough showing the Study Area and Sample Locations

about $100-120 \mathrm{~cm}$ per annum. The annual temperature ranges from $30-35^{\circ} \mathrm{C}$ and the relative humidity is in the order of 30-60\% (Iloeje, 1981). The vegetation in Arufu is the savannah wood type, typified by tall grass, shrub and a few trees ranging in height from 3-6 $\mathrm{m}$.

\section{Geology of Study Area}

The Arufu mining district is within the Benue Trough (Fig. 1). The Benue Trough is about 600 $\mathrm{km}$ long and $80-90 \mathrm{~km}$ wide. It contains up to $5000 \mathrm{~m}$ thick of slight deformed Cretaceous sediments and volcanic rocks (Olade, 1975). Detailed geological mapping of the study area (Pargater, 1959; Reyment, 1965) shows that it is underlain dominantly by Cretaceous sediments comprising shales, sandstones, and limestone. The sediments are intruded by diorite and granites (Fig. 1). There are also the quaternary sediments represented by the alluvial deposits found along stream courses as well as laterite scarps. The sediments are highly folded and faulted into gentle pitching anticlines and domes that usually trend north-south. Faults and fractures trend north-south or northwestsoutheast (Olade, 1976 and Ofoegbu, 1984).
The ore-bodies in the area are structurally controlled. The ore-bodies occur in fault zones, which served as channels for hydrothermal solutions and deposit their metallic and non-metallic minerals. The main mineralization in Arufu occurs as $\mathrm{Pb}-\mathrm{Zn}$ lodes and veins along sheeted zones within carbonate host rocks (Pargater, 1959). The principal ore minerals are galena, sphalerite and chalcophyrite with minor bornite, marcasite and pyrite within a gangue of manganiferous siderite, dolomite, calcite, barite and sericite. In the supergene zone, the primary minerals are replaced by secondary minerals that include cerusite, pyromorphite, anglistite, calamine, malachite, azurite, ferric oxides and minor smithsonite (Abimbola and Akande, 1996).

\section{Materials and Methods}

Rock samples, surface soils at depths of $0-15 \mathrm{~cm}$ and water samples were collected at and around abandoned $\mathrm{Pb}-\mathrm{Zn}$ mines at Arufu (Fig. 1). Bedrock samples were collected by chip sampling along the most continuous accessible outcrops. Soils samples were collected from mine waste and adjoining areas. Water samples were collected 
from mine ponds and surrounding streams. Forest soils were collected in a forest near Makurdi to serve as control samples.

The rock and soil samples were air-dried at room temperature for 72 hours. The rock samples were then crushed to minus 100-mesh and the soil samples sieved through minus 80 mesh and the resulting powders digested with 4:1 mixture of nitric: perchloric acids. The resulting solutions were then stored properly into well labeled test tubes prior to analysis.

Surface water samples were collected in plastic bottles which were pre-soaked in acid washing liquid $\left(1 \% \mathrm{HNO}_{3}\right)$ and washed thoroughly with distilled water samples. At the sample point, the bottles were rinsed with the water before filling the bottle with the water. The water samples were then acidified with $1 \mathrm{M} \mathrm{HNO}_{3}$ in order that the ions remain in solution and to avoid the growth of bacteria and fungus. Samples were then stored in refrigirator prior to analysis within 24 hours.

The digested solutions and water samples were analysed for $\mathrm{Fe}, \mathrm{Zn}, \mathrm{Mn}, \mathrm{Pb}, \mathrm{Cu}, \mathrm{Cr}, \mathrm{Cd}, \mathrm{As}$ and Ag using ASS, Bulk Scientific model 210 at University of Agriculture Makurdi. Data were assessed for accuracy and precision using a quality control system integral to the analytical procedure.

Soil $\mathrm{pH}$ was determined in the laboratory using Hach One-Meter model -43899 from slurry formed by a 1:1 ratio of sample to deionised water. The $\mathrm{pH}$ of water samples was determined in the field using $\mathrm{pH}$ Meter. Soil OM content was estimated from loss on ignition - LOI (Chukwuma, 1995).

\section{Results}

\subsection{Trace Element Concentrations in Rock Sa- mples}

Heavy metals vary considerably among the different lithologies in the study area (Table 1), reflecting the varying abundance and composition of minerals in the bedrock. Thus, compared to the other units, the shales and diorites are characterised by relatively high trace element contents. Although the lowest levels of $\mathrm{Mn}(18 \mathrm{mg} / \mathrm{kg})$ and $\mathrm{Ag}(0.06 \mathrm{mg} / \mathrm{kg})$ are associated with the shale. Although the granites are relatively enriched in $\mathrm{Pb}$ $(22 \mathrm{mg} / \mathrm{kg})$ and $\mathrm{Cd}(3 \mathrm{mg} / \mathrm{kg})$, limestone and granite have the lowest concentrations of most trace elements Sandstones have moderate levels of trace elements, despite that they are relatively enriched in As $(2 \mathrm{mg} / \mathrm{kg})$ and have the lowest $\mathrm{Pb}(6 \mathrm{mg} / \mathrm{kg})$ value.

\subsection{Soil and Water Characteristics}

Summary of the soil $\mathrm{pH}, \mathrm{OM}$ and water $\mathrm{pH}$ are listed in Tables 2 and 3 . Table 2 shows that soil samples are weakly acidic to alkaline with $\mathrm{pH}$ ranging from $6.30-8.00$ with a mean value of $6.99 \pm 0.16$. While the OM varied from $2-10 \%$ with mean of $4 \pm 1.13 \%$ implying that the soil contains low OM. The mean value of the water $\mathrm{pH}$ $6.3 \pm 1.20$ and range of 5.80 to 7.60 (Table 3 ) indicate a weakly acidic to alkaline nature or moderate $\mathrm{pH}$ of the water.

\subsection{Trace Metal Concentration in Soil and Wa- ter Samples}

The range and mean concentration of $\mathrm{Ag}, \mathrm{As}, \mathrm{Cd}$, $\mathrm{Cr}, \mathrm{Cu}, \mathrm{Fe}, \mathrm{Mn}, \mathrm{Pb}$, and $\mathrm{Zn}$ in surface soil samples of the study and control areas as well as mean values common in soil (Rose, et al. 1979) are listed in Table 2. The concentrations of the trace elements in the study area are comparable to those of the control (forest soils) and are within the world mean values as quoted by Rose, et al. (1979) except for $\mathrm{Zn}$ (mean, $181 \pm 83 \mathrm{mg} / \mathrm{kg}$; range $18-420$ $\mathrm{mg} / \mathrm{kg}$ ), $\mathrm{Pb}$ (mean, $40 \pm 28 \mathrm{mg} / \mathrm{kg}$; range $12-130 \mathrm{mg} /$ $\mathrm{kg}$ ) and $\mathrm{Cd}$ (mean $3 \pm 2 \mathrm{mg} / \mathrm{kg}$; range $1-6 \mathrm{mg} / \mathrm{kg}$ ). Table 3 presents the mean and range of the concentrations of $\mathrm{Ag}, \mathrm{As}, \mathrm{Cd}, \mathrm{Cr}, \mathrm{Cu}, \mathrm{Fe}, \mathrm{Mn}, \mathrm{Pb}$ and $\mathrm{Zn}$ in water samples of the study area together with acceptable limits of WHO (1993).

\section{Discussion}

The $\mathrm{pH}$ obtained for soils in the study area is comparable to that of the control (forest soils) with mean of $5.68 \pm 0.25$ and it is also within the world mean values (Rose, et al., 1979) indicating normal soil $\mathrm{pH}$ (Table 2). The relative low content of OM in soils samples from tailings $(4 \pm 1.13 \%)$ as compared to forest soils $(10+3 \%)$ could be attributed to the relative scarce and slow rate of biological decomposition of vegetation in the study area. This may also partly account for the moderate $\mathrm{pH}$ values encountered in the study area. The low OM content of the soils also implies that organometallic complexion which increases the mobility of metals in the secondary environment (Cox, 1995) is minimal in the area of the study.

The mean $\mathrm{pH}$ of 6.3 obtained in water samples in this study (Table 3) is slightly above the mean value of 5.9 obtained by Ofulume, et al. (2004) from water samples collected in the vicinity of the $\mathrm{Pb}-\mathrm{Zn}$ mining district of Ebonyi State, lower Benue Trough. This moderate $\mathrm{pH}$ of the water and soil samples probably reflects some interaction with the limestone in the area. Most fresh waters are not saturated with calcium carbonate $\left(\mathrm{CaCO}_{3}\right)$ and so readily dissolve it leading to increase in $\mathrm{pH}$ (Hem, 1985). The waste rock and tailings with significantly reduced particle sizes result in considerable increase in carbonate dissolution. 
Table 1 Trace Element Composition of Rocks from the Study Area

\begin{tabular}{|l|c|c|c|c|c|c|c|c|c|}
\hline Rock & \multicolumn{9}{|c|}{ Trace Elements Concentration (mg/kg) } \\
\hline & $\mathbf{F e}$ & $\mathbf{Z n}$ & $\mathbf{C u}$ & $\mathbf{M n}$ & $\mathbf{P b}$ & $\mathbf{C d}$ & $\mathbf{C r}$ & $\mathbf{A s}$ & $\mathbf{A g}$ \\
\hline Biotite Granite (n=5) & 18.00 & 31.00 & 11.00 & 36.00 & 22.00 & 3.00 & 0.20 & 0.20 & 0.10 \\
& & & & & & & & & \\
\hline Diorite (n=5) & 31.00 & 64.00 & 14.00 & 45.00 & 13.00 & 2.00 & 0.60 & 0.30 & 2.00 \\
\hline Sandstone (n=6) & 28.00 & 47.00 & 6.00 & 33.00 & 6.00 & 2.00 & 0.40 & 2.00 & 0.20 \\
\hline Limestone (n=6) & 15.00 & 61.00 & 4.00 & 30.00 & 13.00 & 2.00 & 0.80 & 0.30 & 0.20 \\
\hline Shales (n=5) & 32.00 & 35.00 & 7.00 & 18.00 & 21.00 & 3.00 & 1.00 & 0.40 & 0.06 \\
\hline
\end{tabular}

Table 2 Mean \pm Sd and Range of Values of Chemical Analysis of Soil Samples in the Study Srea with the Ranges of their Mean Abundance

\begin{tabular}{|c|c|c|c|}
\hline Parameter & $\begin{array}{l}\text { Arufu } \\
\text { (Tailings) } \\
(\mathrm{n}=\mathbf{4 0}) \\
\end{array}$ & $\begin{array}{l}\text { Forest } \\
\text { Soil* } \\
(n=40) \\
\end{array}$ & $\begin{array}{l}\text { General } \\
\text { mean } \\
\text { abundance }^{\text {ab }}\end{array}$ \\
\hline $\mathrm{Fe}(\mathrm{mg} / \mathrm{kg})$ & $\begin{array}{l}164 \pm 44 \\
(32-274)\end{array}$ & $\begin{array}{l}171 \pm 24 \\
(120-300)\end{array}$ & $1-2 \%$ \\
\hline $\mathrm{Zn}(\mathrm{mg} / \mathrm{kg})$ & $\begin{array}{l}181 \pm 83 \\
(18-420)\end{array}$ & $\begin{array}{l}85 \pm 15 \\
(25-150)\end{array}$ & $36-100$ \\
\hline $\mathrm{Mn}(\mathrm{mg} / \mathrm{kg})$ & $\begin{array}{l}140 \pm 52 \\
(10-300)\end{array}$ & $\begin{array}{l}120 \pm 21 \\
(90-200)\end{array}$ & $300-400$ \\
\hline $\mathrm{Pb}(\mathrm{mg} / \mathrm{kg})$ & $\begin{array}{l}40 \pm 28 \\
(12-130)\end{array}$ & $\begin{array}{l}20 \pm 9 \\
(7-31) \\
\end{array}$ & $17-30$ \\
\hline $\mathrm{Cu}(\mathrm{mg} / \mathrm{kg})$ & $\begin{array}{l}20 \pm 14 \\
(4-60)\end{array}$ & $\begin{array}{l}34 \pm 16 \\
(20-50)\end{array}$ & $20-50$ \\
\hline $\mathrm{Cd}(\mathrm{mg} / \mathrm{kg})$ & $\begin{array}{l}3 \pm 2 \\
(1-6)\end{array}$ & $\begin{array}{l}2 \pm 0.05 \\
(0.1-3)\end{array}$ & $0.1-0.5$ \\
\hline As (mg/kg) & $\begin{array}{l}3 \pm 0.8 \\
(1-5)\end{array}$ & $\begin{array}{l}2 \pm 0.5 \\
(1-3)\end{array}$ & $5-10$ \\
\hline $\mathrm{Cr}(\mathrm{mg} / \mathrm{kg})$ & $\begin{array}{l}2 \pm 0.3 \\
(0.08-3)\end{array}$ & $\begin{array}{l}42 \pm 18 \\
(20-60)\end{array}$ & $40-50$ \\
\hline $\mathrm{Ag}(\mathrm{mg} / \mathrm{kg})$ & $\begin{array}{l}0.30 \pm 0.14 \\
(0.08-3)\end{array}$ & $\begin{array}{l}0.2 \pm 0.04 \\
(0.1-0.3) \\
\end{array}$ & $0.2-0.5$ \\
\hline Om (L01)\% & $\begin{array}{l}4 \pm 1.13 \\
(2-10)\end{array}$ & $\begin{array}{l}10 \pm 3 \\
(5-20)\end{array}$ & - \\
\hline $\mathrm{pH}$ & $\begin{array}{l}6.99 \pm 0.16 \\
(6.30-8.00)\end{array}$ & $\begin{array}{l}6.68 \pm 0.25 \\
(5.80- \\
7.60)\end{array}$ & $6.50-8.50$ \\
\hline
\end{tabular}

a World mean abundance after Rose, et al (1979) *Control area

Apart from $\mathrm{Zn}, \mathrm{Pb}$ and $\mathrm{Cd}$, the levels of trace elements in soils are within mean values of Rose, et al. (1979) and similar to those of the control (forest) area. However, enhanced levels of these elements are restricted to the soil samples collected from mine waste (tailings). Oxidation of sulphide minerals is known to cause the release of high level of metals from exposed tailings or mine waste (Sidenko, et al., 2007; Johnson, et al. 2000).

In the study area the source of these metals are probably from the oxidation of exposed sulphide minerals such as galena and sphalerite from mine wastes which are then leached into soils during
Table 3 Mean + SD and Range of Value of Se lected Elements in Water Samples along side WHO (1993) Standard

\begin{tabular}{|l|c|c|c|}
\hline \multirow{2}{*}{ Parameter } & \multicolumn{2}{|c|}{ Water samples (n = 10) } & $\begin{array}{l}\text { WHO (1993) } \\
\text { standard limit for } \\
\text { driking water } \\
\text { (mg/l) }\end{array}$ \\
\cline { 2 - 4 } & Mean \pm SD & Range & 0.30 \\
\hline $\mathrm{Fe}(\mathrm{mg} / \mathrm{l})$ & $0.09 \pm 0.02$ & $0.02-0.20$ & 5.00 \\
\hline $\mathrm{Zn}(\mathrm{mg} / \mathrm{l})$ & $1.5 \pm 0.50$ & $0.80-2.30$ & 0.05 \\
\hline $\mathrm{Mn}(\mathrm{mg} / \mathrm{l})$ & $0.04 \pm 0.01$ & $0.03-0.05$ & 0.05 \\
\hline $\mathrm{Pb}(\mathrm{mg} / \mathrm{l})$ & $0.05 \pm 0.01$ & $0.02-0.10$ & 1.00 \\
\hline $\mathrm{Cu}(\mathrm{mg} / \mathrm{l})$ & $0.08 \pm 0.02$ & $0.05-0.10$ & 0.005 \\
\hline $\mathrm{Cd}(\mathrm{mg} / \mathrm{l})$ & $0.03 \pm 0.01$ & $0.02-0.04$ & 0.05 \\
\hline $\mathrm{As}(\mathrm{mg} / \mathrm{l})$ & $0.02 \pm 0.005$ & $0.1-0.30$ & 0.05 \\
\hline $\mathrm{Cr}(\mathrm{mg} / \mathrm{l})$ & $0.02 \pm 0.001$ & $0.01-0.03$ & 0.001 \\
\hline $\mathrm{Ag}(\mathrm{mg} / \mathrm{l})$ & $\mathrm{ND}$ & $\mathrm{ND}$ & $6.5-8.5$ \\
\hline $\mathrm{pH}$ & $6.3 \pm 1.20$ & $5.6-7.8$ & \\
\hline
\end{tabular}

heavy precipitation (Chen, et al., 1997; Romero, et al., 2007). These sulphide minerals are associated with the $\mathrm{Pb}-\mathrm{Zn}$ mineralization in the Arufu mining district (Abimola and Akanda, 1996). Similar conclusions have been reached in other mining districts of Benue Trough by Adiuku-Brown and Ogezi (1991) and Chukwuma (1995). Fisher (1998) and Kelepertisis and Bibou (1991), have also reached similar conclusions from the study of $\mathrm{Pb}-\mathrm{Zn}$ mining districts.

Levinson (1974), Thornton and Plant (1980), Cox (1995) are of the opinion that lithology is one of the major controls on the levels of variability of trace elements in the soils and that the portion of any area characterized by high content of a given trace element is usually very small. The higher levels of trace elements in soil samples relative to the parent materials (Tables 1 and 2) could be attributed to modifications by soil forming processes such as leaching, podzolization and accumulation by OM, colloids and Fe-Mn oxides (Harter, 1992). These processes are known to control the level and distribution of trace elements in the soils and are 
known to depend on one or a combination of such soil properties like $\mathrm{pH}$, water content (drainage), soil biology, redox potentials, salinity, soil grain size among others (De Bustamante, 1990).

The concentrations of $\mathrm{Ag}, \mathrm{As}, \mathrm{Cd}, \mathrm{Pb}$ and $\mathrm{Zn}$ in soil were found to be enriched within the mineralized bedrock and to a lesser extent over diorites and shales. Whereas the soils that developed over barren limestone were characterized by low values of these metals (Table 1). The variability in levels and composition of trace elements in the bedrock is reflected in the soil samples (Table 1 and 2) and it suggests that in situ weathering from the bedrock is a major source of trace elements in soils of the study area.

All the mean values of trace elements obtained in the water samples are within the maximum permissible limits (WHO, 1993) in water for domestic and other purposes except for $\mathrm{Pb}(0.05 \pm 0.01 \mathrm{mg} /$ 1) and $\mathrm{Cd}(0.03 \pm 0.01 \mathrm{mg} / \mathrm{l})$ (Table 3$)$. The mean levels are also low compared to values obtained by Ofulume, et al. (2004) from the Ishiagu $\mathrm{Pb}-\mathrm{Zn}$ in Lower Benue Trough. Although many factors influence the solubility of trace elements, $\mathrm{pH}$ is known to be of critical importance (Dyek, 1971; Howard, et al., 2006). Most metals are known to be soluble in acidic environments (Cox, 1995; Siegel, 2002). This study has revealed the weakly acidic to alkaline nature or moderate $\mathrm{pH}$ of both soil samples $(\mathrm{pH}$ 63-8.0) and water samples $(\mathrm{pH}$ 5.8 - 7.6) (Tables 2 and 3) which most probably reflect some interaction with the limestone in the area. Thus waste rock and tailings where particles size has been significantly reduced result in a considerable increase in surface area and promote increase in carbonate dissolution. Under the weakly acidic to alkaline conditions in this area, in -situ leaching and migration in waters (hydromorphic distribution) is less effective. Clastic dispersion by man, wind and water is probably most effective in the distribution of elements in soil and water samples of the study area. This corroborates the views of Yung, et al. (2001).

The enhanced values of $\mathrm{Pb}(0.10 \mathrm{mg} / \mathrm{l})$ and $\mathrm{Cd}$ $(0.03 \mathrm{mg} / \mathrm{l})$ are mainly associated with water samples from mine ponds (Fig. 2). This indicates that these pollutants are most probably released into the mine ponds during the occasional acidic conditions caused by the oxidation of the sulphide minerals associated with the $\mathrm{Pb}-\mathrm{Zn}$ mineralization in the study area. However, such conditions would most likely accelerate the dissolution of carbonates downstreams thereby increasing the $\mathrm{pH}$ of waters but decreasing their ability to dissolve metals (Kabata-Pendias and Pendias, 2000; Florea, et al. 2005). The environmental significance of this process is that heavy metals in surface soil and water of the study area could easily be removed from the solution and rendered less mobile and unavailable to the biosphere. In order words the bioavailability of heavy metals could be restricted to mine ponds and soils developed on tailings. The indiscriminate application of inorganic fertilizer in the area could however cause large-scale dissolution and mobilization of contaminants (Agbenin, 1998) thereby heightening the potential for their dietary exposure to consumers.

Adiuku-Brown and Ogezi (1991) and Ofulume, et al. (2004) reported higher mean values of $\mathrm{Pb}$ (1.12 and $0.7 \mathrm{mg} / \mathrm{l})$ and $\mathrm{Cd}(1.00$ and $0.2 \mathrm{mg} / \mathrm{l})$ in water sample from Zurak and Ishiagu $\mathrm{Pb}-\mathrm{Zn}$ mining districts of Upper and Lower Benue Trough respectively. This difference may partly be related to the low $\mathrm{pH}$ of waters in these mining districts as against the high $\mathrm{pH}$ values obtained in this study.

$\mathrm{Pb}$ is generally a metabolic poison and enzyme inhibitor. It can cause brain damage and metal retardation to children at high levels (Warren, 1972; Christensen, 1995). Cadmium on the other hand is extremely toxic and can cause hypertension if ingested in large doses (Keller, 1981; Jensen, et al., 2003; Stoica, et al., 2000).

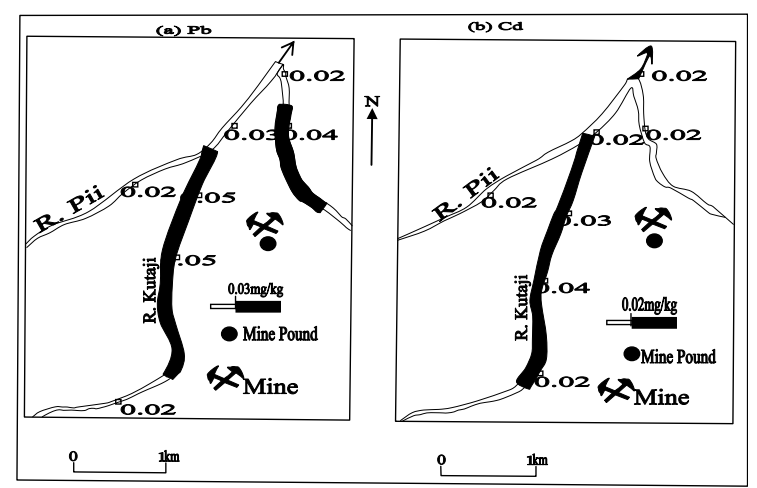

Fig. 2 Distribution of (a) $\mathrm{Pb}$ and (b) $\mathrm{Cd}$ in Mines and Streams in the study Area.

\section{Conclusion and Recommendations}

Results of the study tends to suggest that, mining activities and processing of ores are possible sources of some trace metal pollution of surface soils $(\mathrm{Zn}, \mathrm{Pb}$ and $\mathrm{Cd})$ and surface water $(\mathrm{Pb}$ and $\mathrm{Cd}$ ) in Arufu mining districts. Low contents of heavy metals in the water samples are probably due to low solubility of the metals under low OM content of the soil and moderate $\mathrm{pH}$ of water caused by limestone dissolution. However, enhanced levels of these trace metals are restricted to tailings and mine ponds with acidic environment caused by the weathering of sulphides associated with the $\mathrm{Pb}-\mathrm{Zn}$ mineralization. It would be recommended that investigations be carried out to determine the effects of these pollutants on livestock and human health in the area. The mine 
waste (tailings) should be reclaimed and the mine ponds sealed with limestone bedding to prevent further contamination of the area.

\section{References}

Abimbola, A. F., Akande, S. O. (1996), "Alteration of carbonate host rocks of fluoritelead-zinc mineralization at Arufu-Akwana, Middle Benue Trough, Nigeria", Journal of Mining Geology, 32(1), pp. 19-25.

Adiuku-Brown, M. E., Ogezi, A. E. (1991), "Heavy metal pollution from mining practices: A case study of Zurak", Journal of Mining Geology, 27(2), pp. $205-211$.

Agbenin, J. O. (1998), "Phosphate induced zinc retention in semi-arid soil", European Journal Soil Science, 49, pp. 693 - 700.

Chen, T. B., Wong, W. C., Zhou, H. Y., Wong, M. H. (1997), "Assessment of trace metal distribution and contamination in surface soil of Hong Kong”, Environmental Pollution, 96(1), pp. 61 -68 .

Chukwuma, O. (1995), "Evaluating baseline data for $\mathrm{Cu}, \mathrm{Mn}, \mathrm{Ni}$ and $\mathrm{Zn}$ in rice, yam, cassava and guinea grass from cultivated soil in Nigeria", Agricultural Ecosystem Environment 53, pp. $47-61$.

Cox, P. A. (1995), The elements on earth. Inorganic chemistry in the environment, Oxford University Press Inc. New York, 235 pp.

Christensen, J. M. (1995), "Human exposure to toxic metals: Factors influencing interpretation of biomonitoring results", Science of the Total Environment, 166, pp. $89-135$.

De Bustamante, T. (1990), "Land application; its effectiveness in purification of urban and industrial waste-waters in La Manacha, Spain", Environmental Geology and Water Science, 163 , pp. $179-185$.

Dyek, W. (1971), "The adsorption and coprecipitation of silver on hydrous oxides of iron and manganese", Geological Survey, Canada, pp. $64-70$.

Fisher, B.E. (1998), "Between a rock and a health place", Environmental Health Persp., 100(1), A544 - A546.

Florea, R. M., Stoica, A. L., Balalescu, G. E., Capota, P. (2005), "Water pollution in gold mining industry: A case study in Rosia Montana district, Romania", Environmental Geololgy, 48 , pp. $1132-1136$.

Harter, R. D. (1992), "Competitive sorption of Co, $\mathrm{Cu}$ and $\mathrm{Ni}$ ions by $\mathrm{Ca}$ saturated soil", Journal of Soil Science Society of America, 43(4), pp. $676-683$.

Hem, J. D. (1985), Study and interpretation of the chemical characteristics of natural waters, $3^{\text {rd }}$ ed. US Geol. Survey water supply paper, 1473, Harvard University Press, Massachusetts.

Howard, I. C., Horsfall, M., Spiff, I. A., Teme, S. C., (2006), "Heavy metals levels in surface waters and sediments in an oilfield in Niger Delta, Nigeria", Global Journal of Pure and Applied Sciences, 12(1), pp. 79 - 82.

Iloeje, N. P. (1981), A New Geography of Nigeria, Longman Ltd. Benin, 200 pp.

Jensen, C. R., Heijerick, D. G., DeSchamphelaere, K. A. C., Allen, H. E. (2003), "Environmental risk assessment of metals: Tools incorporating bioavailability", Environment Int. 28, pp. 793 -800 .

Johnson, R. H., Blowes, D. W., Robertson, W. D., Jamber, J. L. (2000), "The hydrogeochemistry of Nickel Rim mine tailings impoundment: Sudbury, Ontario", Journal of Contaminant Hydrology, 41, pp. 48-80.

Jung, M. C. (2001), "Heavy metal contamination of soils and water in and around the Imcheon Au-Ag mine, Korea", Applied Geochemistry 16, pp.1369- 1375 .

Kabata-Pendias, A., Pendias, H. (2000), Trace elements in soils and plants, CRS Press, Boca Raton, New York, 432 pp.

Kelepertsis, A. E., Bibou, A. (1991), "Heavy metal contamination of soil at old mining sites on Thasos Island, Greece", Environmental Geochemistry and Health, 13, pp. 23 - 28.

Keller, E. A. (1981), Environmental Geology, $3^{\text {rd }}$ ed. Charles Publishing Company Ohio, USA, $730 \mathrm{pp}$.

Levinson, A. A. (1974), Introduction to Exploration Geochemistry, Appleton Publishing Ltd. Illinois, USA, 614 pp.

Mills, F. C. (1995), Ecological Toxicology, $3^{\text {rd }}$ ed. Phenum Press, London, 270 pp.

Ofoegbu, C. O. (1984), "A model for tectonic evolution of Nigeria", Geol. Rdsch. 73, pp. 1007 1018.

Ofulume, A. B., Ogbonna, C. P., Aja, G. C. (2004), "Geoenvironmental evaluation of Isiagu lead-zinc mining town of Ebonyi State S.E. Nigeria", Advances in Geosciences, 2, pp. $32-43$.

Olade, M. A. (1975), "Evolution of Nigeria's Benue Trough (aulacogen): a tectonic model", Geological Magazine, 112(1), pp. 575-583.

Olade, M. A. (1976), “On the genesis of lead-zinc deposits in Nigeria's Benue rift (aulacogen): a reinterpretation", Journal of Mining Geology, 13 , pp. $20-27$.

Pargater, R. C. (1959), "The geology of the Pb-Zn deposit at Arufu and Akwana, Benue Province", Geological Survey, Unpublished Report. No.1179.

Pouyat, R. V., McDonnell, M. J. and Pickett, S. T. A. (1995), "Soil characteristics of Oak stands along an urban-rural land use gradient", Pedo- 
biologia, 38(5), pp. $385-399$.

Reyment, R. A. (1965), Aspects of the Geology of Nigeria. Ibadan University Press, Ibadan, Nigeria, $145 \mathrm{pp}$.

Romero, F. M., Armienta, M. A., GonzalezHernandez, G. (2007), "Solid-phase control on the mobility of potentially toxic elements in an abandoned $\mathrm{Pb}-\mathrm{Zn}$ mine tailing impoundment, Taxco, Mexico", Applied Geochemistry 22, pp. $109-127$.

Rose, A. W., Hawkes, H. E., Webb, J. S. (1979), Geochemistry in Mineral Exploration, $2^{\text {nd }}$ ed. Academic Press London, 562 pp.

Siegel, F. R. (2002). Environmental Geochemistry of Potentially Toxic Metals. Springer-Verlag, Berlin, $218 \mathrm{pp}$.

Sidenko, N. Y., Khozhina, E. L., Sheriff, B. L. (2007), "The cycling of Ni, $\mathrm{Zn}, \mathrm{Cu}$ in the system "mine tailings-groundwater": A case study, Applied Geochemistry 221, pp. 30 - 52.

Stoica, A. I., Baialesas, G. E., Abould-Enein, H. Y. (2000), "Analytical studies in the pollution of Arges River", Toxical and Environmental Chemistry, 77, pp. $143-145$.

Thoronton, I. and Plant, J. (1980), "Regional geochemical mapping and health in the UK", Journal of the Geological Society, London, 137, pp. 575-586.

Warren, H. V. (1972), "Geology and medicine", Western Miner, 9, pp. 34-37.

Wong, J. W. C. (1996), "Heavy metal contents in vegetable and market garden soils in Hong Kong”, Environmental Technology, 17, pp. $407-410$.

World Health Organization (WHO, 1993), Guidelines for drinkssing water quality $2^{\text {nd }}$ ed. (Vol. 1), Recommendations, Geneva.

Yung, S. T., Jung, H. B., So, S. C. (2001), "Transport, fate and speciation of heavy metals $(\mathrm{Pb}, \mathrm{Zn}, \mathrm{Cu}, \mathrm{Cd})$ in mine drainage: Geochemical modeling and anodic stripping volumetric analysis", Environmental Technology, 22, pp. $749-770$.

\section{Authors}

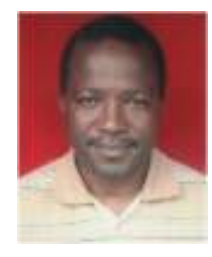

Christopher Iorfa Adamu received his BSc degree in Applied Geology from the Ahmadu Bello University Zaria, Nigeria in 1987. He obtained his MSc degree from the University of Calabar, Nigeria in 2003. He is currently pursuing a PhD in Environmental Geosciences at the University of Calabar, Nigeria. He has successfully completed his thesis entitled 'Geoenvironmental studies of barite mines in parts of Oban massif and Mamfe embayment southeastern Nigeria' and he is awaiting oral examination. Mr. Adamu is a Lecturer at the College of Advanced Proffessional Studies, Makurdi, Nigeria.

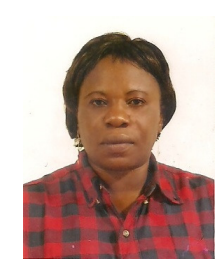

Therese. N. Nganje received her BSc (Hons) degree in Geology, MSc degree and $\mathrm{PhD}$ in Applied Geochemistry (Environmental Geochemistry) from the University of Calabar, Nigeria. She also holds a United Nations Educational, Scientific, and Cultural Organization/Czech Geological Survey certificate on "Geochemical Exploration Methods and their Environmental Applications". She is currently a Lecturer at the University of Calabar. Dr Nganje is a recipient of the European Association of Organic Geochemist Travel Award (EAOG) and the Commonwealth Post-Doctoral Fellowship. 